\title{
"PELAKSANAAN DISIPLIN PEGAWAI BERDASARKAN PERATURAN PEMERINTAH PEMERINTAH NOMOR 53 TAHUN 2010 TENTANG DISIPLIN PEGAWAI NEGERI SIPIL PADA KEJAKSAAN TINGGI KALIMANTAN TIMUR (Studi Kantor Kejaksaan Tinggi Kalimantan Timur)”
}

\author{
Damayanti dan Hudali Mukti \\ Yanti.mada98@gmail.com, hudalimukti@ymail.com, \\ Fakultas Hukum \\ Proram Studi Ilmu Hukum \\ Universitas Widya Gama Mahakam Samarinda
}

\begin{abstract}
ABSTRAK
Sebagaimana telah diamanatkan di dalam peraturan perundang-undangan, aparatur negara dalam meningkatkan kualitas Aparatur Negara dengan memperbaiki kesejahteraan dan keprofesionalan serta memberlakukan sistem karir berdasarkan prestasi kerja dengan prinsip memberikan penghargaan dan sanksi, maka Aparatur Negara hendaknya dapat bersikap disiplin dalam mewujudkan pemerintahan yang bersih dan berwibawa. Pendayagunaan Aparatur Negara terus ditingkatkan terutama yang berkaitan dengan kualitas, efisiensi pelayanan dan pengayoman pada masyarakat serta kemampuan professional dan kesejahteraan aparat sangat di perhatikan dalam menunjang pelaksanaan tugas. Namun pada kenyataannya masih saja banyak aparatur negara yang melakukan pelanggaran yang berupa Sanksi Berat contohnya yang terjadi di Lingkungan Kejaksaan Tinggi sebagai Satya Adhi Wicaksana. Untuk menciptakan pemerintahan yang bersih dan berwibawa, tentunya di perlukan kedisiplinan para aparat pemerintah dan administrasi kepegawaian. Oleh karena itu diperlukan suatu perangkat peraturan yang dapat mendukung terciptanya kedisiplinan pegawai.
\end{abstract}

Kata Kunci: Disiplin Pegawai, Implementasi Peraturan Pemerintah tentang disiplin pegawai.

\begin{abstract}
As has been mandated in legislation, the state apparatus in improving the quality of Administrative by improving welfare and professionalism as well as enacting system careers based on performance with the principle of reward and punishment, the State Apparatus should be able to be disciplined in achieving good governance and authoritative. Administrative Reform continues to be improved, especially with regard to quality, service efficiency, and protection of the public as well as professional skills, and well-being are all concerned agencies in supporting the implementation of tasks. In fact still many state officials who commit violations in the form of sanctions Weight Environmental example that occurred in the high Court as Satya Adhi Wicaksana. In order To create clean governance and authoritative, certainly needed discipline of the officials and personnel administration. Therefore we need a set of rules that can support the creation of employee discipline.
\end{abstract}

Keywords: Employee Discipline, Implementation of Government Regulation on discipline. 


\section{PENDAHULUAN}

\section{A. Latar Belakang}

Upaya reformasi birokrasi merupakan bagian dari grand desain penciptaan pemerintahan yang baik (good governance). Kondisi ini diharapkan mampu menjembatani suatu kondisi pemerintahan yang buruk kearah terbentuknya pemerintahan yang baik. Pendayagunaan aparatur negara terus ditingkatkan terutama yang berkaitan dengan kualitas, efisiensi pelayanan dan pengayoman pada masyarakat serta kemampuan professional dan kesejahteraan aparat sangat di perhatikan dalam menunjang pelaksanaan tugas. Undangundang Pokok Kepegawaian yaitu Undangundang Nomor 8 tahun 1974 telah dirubah melalui Undang-undang Nomor 43 tahun 1999 tentang Pegawai Negeri Sipil, dan diatur lebih lanjut melalui Peraturan Pemerintah Nomor 53 Tahun 2010 Tentang Disiplin Pegawai Negeri adalah suatu landasan hukum untuk menjamin pegawai negeri dan dapat di jadikan dasar untuk mengatur penyusunan aparatur negara yang baik dan benar.

Kedudukan pegawai negeri sipil dalam kehidupan bangsa dan negara pada masa-masa ini mempunyai posisi yang penting dan kompleks. Bukankah kegiatan perencanaan dan pelaksanaan pembangunan pada dasarnya dilakukan oleh pegawai negeri sebagai aparatur negara. Peran pegawai negeri sipil masih sangat penting dalam tata kehidupan masyarakat oleh karena para pegawai negeri itu mempunyai status yang tinggi di mata masyarakat dan oleh karena itu mereka pada umumnya dipandang sebagai suatu kelompok elite tertentu dimasyarakat. Dengan melihat kedudukan pegawai negeri yang penting dan kompleks inilah yang menempatkan dia untuk selalu dibayang-bayang oleh bahayabahaya ataupun godaan-godaan karena kedudukannya itu, sehingga dapat memperlemah peranannya. Adapun sistem prestasi kerja, dimana pengangkatan seseorang untuk menduduki suatu jabatan atau untuk kenaikan pangkat didasarkan atas kecakapan dan prestasi kerja yang di capai oleh pegawai. Kecakapan tersebut harus dibuktikan dengan tulus dalam ujian dinas dan prestasi di buktikan secara nyata dan sistem prestasi kerja ini tidak memberikan penghargaan terhadap masa kerja.

Pegawai negeri bukan saja unsur aparat negara tetapi juga merupakan abdi negara dan abdi masyarakat yang selalu hidup ditengah masyarakat dan bekerja untuk kepentingan masyarakat, oleh karena itu dalam pelaksanaan pembinaan pegawai negeri bukan saja dilihat dan diperlakukan sebagai aparatur negara, tetapi juga dilihat dan diperlakukan sebagai warga negara. Hal ini mengandung pengertian, bahwa dalam melaksanakan pembinaan hendaknya sejauh mungkin diusahakan adanya keserasian antara kepentingan dinas dan kepentingan pegawai negeri sebagai perorangan dengan ketentuan bahwa apabila ada perbedaan antara kepentingan dinas dan kepentingan pegawai negeri sipil sebagai perorangan, maka kepentingan dinaslah yang harus diutamakan.

Berdasarkan pada hal tersebut, Pegawai Negeri Sipil di Indonesia dipandang masih banyak kekurangan yaitu kurangnya menghargai waktu, mengefisienkan tenaga dan kedisiplinan kerja. Sedangkan pembinaan Pegawai Negeri Sipil diatur dalam pasal 12 ayat (2) Undang-undang Nomor 43 Tahun 1999 tentang pokok-pokok kepegawaian yaitu agar Pegawai Negeri Sipil dapat melaksanakan tugasnya secara berdaya guna dan berhasil guna, maka perlu diatur Pembinaan Pegawai Negeri Sipil secara menyeluruh yaitu suatu pengaturan pembinaan yang berlaku baik Pegawai Negeri Sipil Pusat dengan sendirinya berlaku pula pada Pegawai Negeri yang ada ditingkat daerah, kecuali ditentukan lain oleh Undang-undang. Selain dari pada itu perlu dilaksanakan usaha penertiban dan pembinaan aparatur negara yang meliputi baik struktur, prosedur kerja, kepegawaian maupun sarana dan fasilitas kerja, sehingga keseluruhan aparatur negara baik ditingkat pusat maupun di tingkat daerah benar-benar merupakan aparatur yang ampuh, berwibawa, kuat, berdayaguna, penuh 
kesetiaan, dan ketaatan kepada Pancasila dan Undang-undang 1945, Negara dan Pemerintah. Terkait dengan pembinaan Pegawai Negeri Sipil sebagaimana telah diamanatkan dalam Undang-undang Nomor 43 Tahun 1999, maka salah satu faktor yang dipandang sangat penting dan prinsipil dalam mewujudkan aparatur negara yang bersih dan berwibawa adalah masalah kedisplinan para Pegawai Negeri Sipil dalam melaksanakan tugas pemerintahan sebagai abdi negara dan abdi masyarakat.

Dalam meningkatkan kedisiplinan Pegawai Negeri Sipil tersebut, sebenarnya pemerintah telah memberikan suatu kebijaksanaan dengan dikeluarkannya Peraturan Pemerintah Nomor 53 Tahun 2010 yaitu tentang Disiplin Pegawai Negeri Sipil. Pegawai Negeri Sipil sebagai aparat pemerintah dan abdi masyarakat diharapkan selalu siap sedia menjalankan tugas yang telah menjadi tanggung jawabnya dengan baik, akan tetapi sering terjadi di dalam suatu instansi pemerintah pegawainya melakukan pelanggaran disiplin seperti datang terlambat, pulang sebelum waktunya, dan penyimpanganpenyimpangan lainnya yang menimbulkan kurang efektifnya pegawai yang bersangkutan. Dengan adanya pelanggaran disiplin sebagaimana tersebut di atas, yang kesemuanya menunjukkan adanya pelanggaran terhadap disiplin kerja pegawai yang menimbulkan suatu pertanyaan yaitu apakah pelanggaran-pelanggaran tersebut sudah sedemikian membudaya sehingga sulit untuk diadakan pembinaan atau penertiban sebagaimana telah diatur dalam Undang-undang Nomor 43 Tahun 1999.

Kaitannya dengan kedisplinan, Kejaksaan Negeri sebagai lembaga penegak hukum, maka kedisplinan pegawai sangat penting untuk menciptakan pemerintah yang bersih dan berwibawa. Adapun data mengenai penjatuhan hukuman disiplin berdasarkan Peraturan Pemerintah Nomor 53 Tahun 2010 tentang Disiplin Pegawai Negeri Sipil di lingkungan Kejaksaan Tinggi Kalimantan Timur.

Tabel 1.

Rekapitulasi Penjatuhan Hukuman disiplin dari Tahun 2010-2015

\begin{tabular}{|c|c|c|c|c|}
\hline Tahun & Ringan & $\begin{array}{l}\text { Hukuman } \\
\text { Disiplin } \\
\text { Sedang }\end{array}$ & Berat & Keterangan \\
\hline 2010 & - & 1 & - & $\begin{array}{lllll}\begin{array}{l}\text { Penundaan } \\
\text { Tahun }\end{array} & \text { Kenaikan Pangkat Selama } & 1 \\
& & & & \end{array}$ \\
\hline 2011 & - & 8 & - & $\begin{array}{l}\text { Penundaan Kenaikan Pangkat Selama } 1 \\
\text { Tahun }\end{array}$ \\
\hline 2012 & - & 5 & 1 & $\begin{array}{l}\text { Penurunan Pangkat setingkat lebih rendah } \\
\text { selama 1 Tahun dan Penurunan Pangkat } \\
\text { setingkat lebih rendah selama } 3 \text { Tahun }\end{array}$ \\
\hline 2013 & - & 2 & 1 & $\begin{array}{l}\text { Penundaan kenaikan pangkat selama } 1 \text { tahun, } \\
\text { penundaan kenaikan gaji berkala dan } \\
\text { pembebasan dari Jabatan Fungsional Jaksa } \\
\text { selama } 2 \text { tahun }\end{array}$ \\
\hline 2014 & - & - & 1 & Pembebasan fungsional jaksa selama 2 tahun \\
\hline 2015 & - & 1 & - & $\begin{array}{l}\text { Penundaan Kenaikan Pangkat selama } 1 \\
\text { Tahun }\end{array}$ \\
\hline
\end{tabular}

\author{
Berdasarkan latar belakang tersebut, \\ dimana banyaknya penyimpangan- \\ penyimpangan yang dilakukan oleh Pegawai \\ Negeri Sipil terhadap tugasnya terutama pada
}

kantor Kejaksaan Tinggi Kalimantan Timur di Samarinda, untuk itu penulis merasa tertarik untuk melakukan penelitian mengenai disiplin pegawai negeri, karena berdasarkan fenomena- 
fenomena yang terjadi banyak ditemukan pelanggaran salah satunya banyaknya pegawai negeri sipil yang mangkir selama jam kerja dan

beberapa hal lainnya yang berkaitan dengan disiplin. Seharusnya pegawai negeri sipil menjadi abdi masyarakat dan suri tauladan.

\section{B. Permasalahan}

Berdasarkan pada latar belakang tersebut di atas dan banyaknya permasalahan yang ada mengenai kedisiplinan Pegawai Negeri Sipil, maka dapat penulis rumuskan permasalahan sebagai berikut:

1. Bagaimana Pelaksanaan Peraturan Pemerintah Nomor 53 Tahun 2010 tentang Kedisplinan Pegawai Negeri Sipil di Kejaksaan?

2. Apa saja hambatan-hambatan yang timbul dalam meningkatkan kedisiplinan Pegawai Negeri Sipil di Kejaksaan?

\section{Tujuan dan Manfaat Penelitian}

Adapun Tujuan Penelitian ini adalah:

a. Untuk mengetahui pelaksanaan peraturan Disiplin Pegawai Negeri Sipil berdasarkan Peraturan Pemerintah Nomor 53 Tahun 2010 tentang Disiplin Pegawai Negeri di Kejaksaan.

b. Untuk mengetahui apa saja hambatanhambatan yang timbul dalam meningkatkan Kedisiplinan Pegawai Negeri Sipil di Kejaksaan Negeri Samarinda.

Adapun Manfaat Penelitian ini adalah:

Hasil penelitian ini diharapkan dapat memberikan masukan kepada ilmu hukum, khususnya dalam bidang hukum administrasi negara tentang Pelaksanaan Peraturan Disiplin Pegawai Negeri Sipil dan Pemberian Sanksi terhadap Pegawai Negeri Sipil yang melakukan Pelanggaran Disiplin.

\section{BAB II METODE PENELITIAN}

\section{Jenis Penelitian}

Berdasarkan perumusan masalah dan tujuan penelitian, maka metode pendekatan yang digunakan dalam penelitian ini adalah pendekatan Yuridis Normatif.

\section{Sumber Data}

Adapun sumber data yang penulis gunakan dalam penelitian ini adalah, sebagai berikut :

1. Bahan Hukum Primer,yaitu bahan hukum yang bersifat mengikat yang terdiri dari:

a. Undang-undang Nomor 43 Tahun 1999 tentang Pokok-pokok Kepegawaian

b. Peraturan Pemerintah Nomor 8 Tahun 1974, tentang Pembatasan Kegiatan Pegawai Negeri dalam Usaha Swasta

c. Peraturan Pemerintah Nomor 53 Tahun 2010 tentang Disiplin Pegawai Negeri Sipil

d. Surat Edaran Kepala Badan administrasi Kepegawaian Nomor 23/SE/1980, tentang Peraturan Disiplin Pegawai Negeri Sipil

e. Peraturan Jaksa Agung RI Nomor PER022/A/JA/03/2011 tentang penyelenggaraan. Pengawasan Kejaksaan RI dan Juklak Jaksa Agung Muda Pengawasan tentang Teknis Penanganan Laporan Pengaduan dan Tata Kelola Administrasi Bidang Pengawasan.

f. Surat Keputusan Wakil Jaksa Agung RI Nomor KEP-IV-06/B/WJA/01/2015 tanggal 30 Januari tentang Penjatuhan Hukuman Disiplin Tingkat Sedang.

g. Surat Keputusan Jaksa Agung RI Nomor KEP-191/A/JA/12/2013 tanggal 02 Desember 2014 tentang Penjatuhan Hukuman Disiplin Tingkat Berat.

h. Surat Keputusan Jaksa Agung RI Nomor KEP-IV-863/C.4/11/2011 tanggal 21 Nopember 2011 tentang Penjatuhan Hukuman Disiplin Tingkat Sedang.

i. Surat Keputusan Wakil Jaksa Agung Nomor KEP-IV-34/B/WJA/06/2013 tanggal 28 Juni 2013 tentang Penjatuhan Hukuman Disiplin Tingkat Berat.

j. Surat Keputusan Wakil Jaksa Agung Nomor KEP-297/B/wja/12/2011 tentang Penjatuhan Hukuman Disiplin Tingkat Sedang.

k. Surat Keputusan Jaksa Agung Muda Pengawasan Nomor R3083/H/Hpu.2/12/2011 tanggal 22 desember 2011 tentang Penundaan Kenaikan Pangkat Tingkat Sedang.

1. Surat Keputusan Jaksa Agung Muda Pengawasan Nomor B099/H/Hjw/11/2011 tanggal 02 Nopember 
2011 tentang Penundaan Kenaikan Pangkat Tingkat Sedang.

m. Surat Keputusan Kepala Kejaksaan Tinggi Kalimantan Timur Nomor R1161/H/Hpu.2/07/2013 tanggal 09 juli 2013 tentang Penjatuhan Hukuman Disiplin Tingkat Sedang.

n. Surat Keputusan Kepala Kejaksaan Tinggi Kalimantan Timur Nomor R2177/H/Hkt.2/10/2010 tanggal 29 Oktober 2010 tentang Penjatuhan Hukuman Disiplin Tingkat Sedang.

o. Surat Keputusan Kepala Kejaksaan Tinggi Kalimantan Timur Nomor R1808/H/Hpu.2/08/2011 tanggal 09 Agustus 2011 tentang Penjatuhan Hukuman Disiplin Tingkat Sedang.

2. Bahan Hukum Sekunder, yaitu bahan hukum yang memberi petunjuk dan kejelasan terhadap bahan hukum primer, yang terdiri dari buku-buku literature, makalah, artikel, hasil penelitian dan karya ilmiah lainnya yang berhubungan dengan penelitian ini.

3. Bahan Hukum Tertier, yaitu hukum yang memberi petunjuk maupun penjelasan terhadap bahan hukum primer dan bahan hukum sekunder.

\section{Teknik Pengumpulan Data}

1. Studi Kepustakaan

Yaitu dengan melakukan pencarian literatur-literatur, perundang-undangan, tulisan-tulisan, dan laporan-laporan serta bahan lainnya yang berhubungan atau sesuai dengan permasalahan yang ada di dalam penulisan ini.

2. Studi Dokumen

Yaitu dengan cara mempelajari, mengkaji dan menelaah bahan-bahan hukum, baik bahan hukum primer, bahan hukum sekunder maupun bahan hukum tersier.

\section{Analisis Data}

Dalam penelitian ini analisi yang digunakan oleh penulis adalah analisis deskriptif kualitatif yaitu menguraikan data dengan baik dan benar. Maksudnya wawancara terhadap nara sumber langsung dari Asisten Pengawasan Kejaksaan Tinggi Kalimantan Timur di Samarinda. Selain dengan melakukan wawancara, penulis juga melakukan observasi, serta menelaah literatur- literatur dan peraturan perundangundangan yang berhubungan dengan permasalahan Pelaksanaan Peraturan Disiplin Pegawai Negeri Sipil.

\section{PEMBAHASAN}

\section{A. Pelaksanaan Kedisiplinan Pegawai Negeri Sipil di Lingkungan Kejaksaan Tinggi Kalimantan Timur}

Pada bagian ini dibahas mengenai hasil penelitian tentang pelaksanaan Peraturan Pemerintah Nomor 53 Tahun 2010 di bagian Kepegawaian dan selanjutnya untuk pelaksanaan khususnya dilingkungan Kejaksaan telah diatur dalam petunjuk pelaksana Nomor 001/6/1983 tentang ketentuan-ketentuan penyelenggaraan pengawasan Kejaksaan Republik Indonesia.

Kemudian berdasarkan hasil penelitian, bahwa pelaksanaan kedisiplinan Pegawai Negeri Sipil di Lingkungan Kejaksaan Tinggi Kalimantan Timur, telah di lakukan dengan cara sesuai dengan peraturan perundangundangan yang berlaku yaitu dengan cara:

1. Melakukan pengawasan melekat sebagai upaya pengawasan preventif, untuk mencegah hal-hal yang melanggar disiplin, yaitu dengan cara pengawasan secara langsung dari pimpinan yang berada di atasnya.

2. Pengawasan fungsional yaitu suatu pengawasan yang dilakukan oleh aparat pengawas secara fungsional baik intern maupun ekstern, yang dilaksanakan terhadap pelaksanaan tugas kepegawaian.

3. Pengawasan yang di lakukan dengan cara melakukan inspeksi umum yaitu melaksanakan pemeriksaan semua bidang kerja yang telah di susun dalam tahun kerja.

4. Inspeksi pimpinan yaitu inspeksi yang dilakukan oleh Jaksa Agung Muda bidang pengawasan terhdap tugas dari pimpinan kejaksaan.

5. Melakukan inspeksi khusus yaitu melakukan pemeriksaan andai terjadi penyimpangan atau perbuatan-perbuatan tercela dari pegawai kejaksaan.

Bidang pengawasan telah melakukan pengawasan melekat (Waskat) untuk mengurangi kemungkinan terjadinya perbuatan tercela yang dilakukan oleh pegawai pada 
Kejaksaan Tinggi Kalimantan Timur. Dalam melaksanakan pengawasan terhadap pegawai dalam wilayah hukum Kejaksaan Tinggi Kalimantan Timur tidak bisa berjalan dengan baik apabila hanya dilakukan oleh petugas pada bidang pengawasan saja, karena petugas pada bidang pengawasan hanya bisa memantau pada saat jam kerja sedangkan di luar jam kerja para pegawai kembali ke rumahnya masing-masing. Untuk mewujudkan pelaksanaan peraturan disiplin berjalan sesuai peraturan yang berlaku maka semua unsur pimpinan dan perangkat pelaksana penegakan peraturan dan seluruh pegawai yang ada harus saling mendukung. Pengawasan melekat di maksudkan agar tujuan dan sasaran kegiatan administrasi pemerintahan dapat tercapai secara berdaya guna dan berhasil guna serta dilaksanakan sesuai dengan bidang tugas masing-masing.

Dalam melakukan Pengawasan Melekat, Kejaksaan Tinggi Kalimantan Timur telah melakukan sesuai dengan aturan yang berlaku yaitu berdasarkan Instruksi Presiden No.15 Tahun 1983 tentang Pedoman Pelaksanaan Pengawasan, sedangkan petunjuk pelaksanaannya telah dikeluarkan Instruksi Presiden Nomor 1 Tahun 1989.

Adapun sasaran pengawasan melekat berdasarkan pada Instruksi presiden tersebut adalah:

a. Meningkatkan kedisiplinan pegawai serta prestasi kerja serta pencapaian pelaksanaan tugas.

b. Menekan sekecil mungkin penyalah gunaan wewenang.

c. Mengurangi kebocoran serta pemborosan keuangan negara dan segala bentuk penyimpangan lainnya.

d. Mempercepat penyelesaian permasalahan dan meningkatkan pelayanan masyarakat.

e. Mempercepat pengurusan kepegawaian sesuai dengan peraturan yang berlaku.

Untuk lebih meningkatkan kedisiplinan pegawai di lingkungan Kejaksaan Tinggi Kalimantan Timur, absensi juga merupakan hal yang penting, oleh karena itu dalam pelaksanaan absensi Pegawai Negeri Sipil di lingkungan Kejaksaan Tinggi Kalimantan Timur di adakan dua kali sesuai dengan apa yang telah diatur dalam Peraturan Jaksa Agung
Republik Indonesia Nomor : PER016/A/J.A/07/2013, tentang urusan dalam dilingkungan Kejaksaan RI yang tertuang dalam pasal 14 yaitu pagi hari yang diadakan jam 07.30 WIB dan pada waktu sore hari yang dilakukan pada jam 16.00 WIB. Pelaksanaan absensi dengan menggunakan absen finger print, tetapi dalam kurun waktu 2 (dua) tahun terakhir alat absen finger print tersebut telah rusak dan sampai sekarang belum dilakukan perbaikan. Karena alat absen finger print telah rusak, maka Pimpinan Kejaksaan Tinggi telah menginstruksikan agar dilakukan absen secara manual yang dilakukan disaat pagi hari yang diadakan jam 07.30 WIB dan pada waktu sore hari yang dilakukan pada jam 16.00 WIB.

Dalam hal pembinaan disiplin kerja PNS dilingkungan kejaksaan Tinggi Kalimantan Timur melakukan apel pagi pada setiap hari senin dan dilakukan pengarahan serta himbauan yang disampaikan oleh pimpinan, Jika ada pegawai yang tidak mengikuti apel pagi tersebut, maka akan dipanggil untuk dimintai keterangan alasan ketidakhadirannya tersebut dan kalau tidak bias memberikan alasan yang bisa dipertanggungjawabkan maka akan diberikan teguran. Karena pelaksanaan apel pagi merupakan salah satu kewajiban pegawai pada kejaksaan yang telah diatur dalam Peraturan Jaksa Agung RI Nomor: PER016/A/J.A/07/2013 pasal 15. Untuk menjaga kesehatan jasmani, dilingkungan Kejaksaan Tinggi Kalimantan Timur diadakan senam pagi bersama pada setiap hari jum'at sebagaimana yang telah diatur dalam Peraturan Jaksa Agung RI Nomor: PER-016/A/J.A/07/2013 tentang urusan dalam dilingkungan Kejaksaan Republik Indonesia dalam pasal 128 telah diatur bahwa kegiatan senam pagi merupakan kewajiban dari setiap pegawai.

Dalam melakukan fungsinya, bidang pengawasan pada Kejaksaan Tinggi Kalimantan Timur telah menerima dan menindak lanjuti laporan pengaduan yang berkaitan dengan pelanggaran disiplin yang dilakukan oleh pegawai pada wilayah hukum Kejaksaan Tinggi Kalimantan Timur. Dari triwulan I Sampai dengan triwulan ke III (tiga) Tahun 2014 bidang pengawasan telah menerima dan menindaklanjuti 7 (tujuh) laporan pengaduan pelanggaran disiplin, 3 (tiga) laporan sudah ditangani dan sudah dilaporkan ke Kejaksaan Agung dan 4 (empat) 
laporan pengaduan masih dalam proses pemriksaan oleh bidang pengawasan Kejaksaan Tinggi Kaltim. Setiap laporan pengaduan yang dilaporkan kepada bidang pengawasan akan ditindaklanjuti secepat mungkin, kalau laporan tersebut terbukti maka akan dilakukan proses lebih lanjut dan seandainya tidak ditemukan bukti maka inspeksi kasus terhadap laporan tersebut dihentikan dengan dibuatkan surat keputusannya.

Dalam periode 2013 s/d 2014 bidang pengawasan Kejaksaan Tinggi Kalimantan Timur telah melaksanakan rencana kerja dan program kerja sesuai dengan yang telah ditetapkan, dengan pengukuran kinerja yang mencakup penetapan indicator kinerja dan capaian indikator kinerja. Dari pengukuran kinerja di peroleh evaluasi kinerja kegiatan yaitu:

1. Meningkatkan pengawasan melekat (Waskat) secara berkesinambungan yaitu dengan melakukan pengusutan dan pemeriksaan di tempat (inspeksi kasus) penyimpangan, penyalahgunaan jabatan atau wewenang dan perbuatan tercela lainnya, serta mengusulkan penjatuhan hukuman disiplin terhadap pegawai kejaksaan yang terbukti melakukan perbuatan tercela.

2. Melakukan pengawasan pelaksanaan tugas satuan kerja baik rutin maupun pembangunan dengan menyusun program kerja pengawasan tahunan (PKPT) Tahun 2014 untuk melaksanakan inspeksi umum dan inspeksi pemantauan terhadap 14 (empat belas) unit kerja Kejaksaan seKalimantan Timur, serata melakukan pengamatan, penelitian, pengujian dan penilaian atas surat-surat dan laporan rutin maupun insidentil dari Kejaksaan seKalimantan Timur.

Pelaksanaan Peraturan Pemerintah Nomor 53 Tahun 2010 tentang disiplin Pegawai Negeri Sipil yang dilakukan oleh bidang pengawasan Kejaksaan Tinggi Kalimantan Timur pada Tahun 2013 berdasarkan hasil laporan bulanan bidang pengawasan dari hasil wawancara dengan asisten bidang pengawasan yaitu dalam tabel 1 mengelompokan penjatuhan hukuman disiplin sesuai dengan pangkat dan golongan pegawai yang melanggar disiplin antara lain dari Tata Usaha golongan II sebanyak 1 (satu) orang dan golongan III sebanyak 2 (dua) orang, sedangkan dari Jaksa golongan III sebanyak 7 (tujuh) orang dan golongan IV sebanyak 1 (satu) orang. Dalam tabel 2 bisa di lihat hasil pelaksanaan penegakan peraturan disiplin berdasarkan jenis hukuman yang di jatuhkan yaitu hukuman disiplin ringan terhadap 2 (dua) orang Jaksa, dan jenis hukuman disiplin tingkat sedang dijatuhkan kepada 1 (satu) orang staf Tata Usaha dan 3 (tiga) orang dari Jaksa, sedangkan untuk jenis hukuman tingkat berat di jatuhkan kepada 2 (dua) orang dari staf Tata Usaha dan 3 (tiga) orang dari Jaksa. Dalam tabel 3 bisa kita lihat penjatuhan hukuman disiplin berdasarkan jenis perbuatan yaitu penjatuhan hukuman disiplin karena melakukan perbuatan indisipliner (melanggar disiplin) yang dilakukan oleh staf Tata Usaha berjumlah 3 (tiga) orang dan dari Jaksa berjumlah 8 (delapan) orang.

Pelaksanaan Peraturan Pemerintah Nomor 53 Tahun 2010 tentang disiplin Pegawai Negeri Sipil yang dilakukan oleh bidang pengawasan Kejaksaan Tinggi Kalimantan Timur sudah efektif hal tersebut dapat dilihat dari Tabel nomor 4 yang menunjukkan bahwa setiap tahunnya sudah berkurang pegawai yang melakukan pelanggaran disiplin.

Dalam memahami bentuk disiplin pada PNS, sebagai abdi negara dan masyarakat Pegawai Negeri Sipil perlu mengacu pada peraturan perundang-undangan yang berlaku akan hal ini. Dalam hal Disiplin PNS, kita mempunyai Peraturan Pemerintah No. 30 Tahun 1980 tentang Peraturan Disiplin Pegawai Negeri Sipil. Selama ini seluruh kewajiban dan larangan bagi PNS mengacu pada koridor-koridor pada Peraturan Pemerintah Nomor 30 Tahun 1980 tersebut. Dan pada tahun 2010, peraturan tentang Disiplin PNS disempurnakan lagi dengan dikeluarkannya Peraturan Pemerintah Nomor 53 Tahun 2010 tentang Disiplin Pegawai Negeri Sipil. Peraturan Pemerintah 53 Tahun 2010 ini diberlakukan mulai bulan Juni 2010, sehingga segala hal yang berhubungan dengan Disiplin PNS mengacu pada peraturan pemerintah ini. Jadi, bentuk disiplin bagi PNS adalah yang mengacu pada Peraturan Pemerintah 53 Tahun 2010 yang berisi 17 kewajiban dan 15 larangan, sebagai 
penyempurnaan atas 26 kewajiban dan 18 larangan sebagaimana kita pahami dulu dalam peraturan pemerintah sebelumnya (Peraturan Pemerintah 53 Tahun 2010).

Pelaksanaan penegakan hukum Setiap Pegawai Negeri Sipil Harus bersedia melakukan Kewajiban dan Larangan Sesuai dengan Peraturan Pemerintah 53 Tahun 2010 tentang Disiplin Pegawai pasal 3 (tiga) dan 4 (empat). Pemberian Sanksi PNS yang tidak menaati ketentuan sebagaimana dimaksud dalam Pasal 3(tiga) dan/ atau Pasal 4 (empat) dijatuhi hukuman disiplin. Dengan tidak mengesampingkan ketentuan dalam peraturan perundang-undangan pidana, PNS yang melakukan pelangggaran disiplin dijatuhi hukuman disiplin.

Sebagaimana yang telah diatur dalam bagian kelima Peraturan Pemerintah Nomor 53 Tahun 2010 Pemeriksaan, Penjatuhan, dan Penyampaian Keputusan Hukuman Disiplin menjelaskan tata cara pemanggilan Pegawai Negeri Sipil yaitu:

\section{Pasal 23}

1. PNS yang diduga melakukan pelanggaran disiplin dipanggil secara tertulis oleh atasan langsung untuk dilakukan pemeriksaan.

2. Pemanggilan kepada PNS yang diduga melakukan pelanggaran disiplin dilakukan paling lambat 7 (tujuh) hari kerja sebelum tanggal pemeriksaan.

3. Apabila pada tanggal yang seharusnya yang bersangkutan diperiksa tidak hadir, maka dilakukan pemanggilan kedua paling lambat 7 (tujuh) hari kerja sejak tanggal seharusnya yang bersangkutan diperiksa pada pemanggilan pertama.

4. Apabila pada tanggal pemeriksaan sebagaimana dimaksud pada ayat (3) PNS yang bersangkutan tidak hadir juga maka pejabat yang berwenang menghukum menjatuhkan hukuman disiplin berdasarkan alat bukti dan keterangan yang ada tanpa dilakukan pemeriksaan.

\section{Pasal 24}

1. Sebelum PNS dijatuhi hukuman disiplin setiap atasan langsung wajib memeriksa terlebih dahulu PNS yang diduga melakukan pelanggaran disiplin.

2. Pemeriksaan sebagaimana dimaksud pada ayat (1) dilakukan secara tertutup dan hasilnya dituangkan dalam bentuk berita acara pemeriksaan.
3. Apabila menurut hasil pemeriksaan sebagaimanadimaksud pada ayat (2) untuk menjatuhkan hukuman disiplin kepada PNS tersebut merupakan kewenangan:

a. atasan langsung yang bersangkutan maka atasan langsung tersebut wajib menjatuhkan hukuman disiplin;

b. pejabat yang lebih tinggi maka atasan langsung tersebut wajib melaporkan secara hierarki disertai berita acara pemeriksaan.

\section{Pasal 25}

1. Khusus untuk pelanggaran disiplin yang ancaman hukumannya sebagaimana dimaksud dalam Pasal 7 ayat (3) dan ayat (4) dapat dibentuk Tim Pemeriksa.

2. Tim Pemeriksa sebagaimana dimaksud pada ayat (1) terdiri dari atasan langsung, unsur pengawasan, dan unsur kepegawaian atau pejabat lain yang ditunjuk.

3. Tim Pemeriksa sebagaimana dimaksud pada ayat (1)dibentuk oleh Pejabat Pembina Kepegawaian atau pejabat lain yang ditunjuk.

\section{Pasal 26}

Apabila diperlukan, atasan langsung, Tim Pemeriksa atau pejabat yang berwenang menghukum dapat meminta keterangan dari orang lain.

\section{Pasal 27}

1. Dalam rangka kelancaran pemeriksaan, PNS yang diduga melakukan pelanggaran disiplin dan kemungkinan akan dijatuhi hukuman disiplin tingkat berat, dapat dibebaskan sementara dari tugas jabatannya oleh atasan langsung sejak yang bersangkutan diperiksa.

2. Pembebasan sementara dari tugas jabatannya sebagaimana dimaksud pada ayat (1) berlaku sampai dengan ditetapkannya keputusan hukuman disiplin.

3. PNS yang dibebaskan sementara dari tugas jabatannya sebagaimana dimaksud pada ayat (1) tetap diberikan hak-hak kepegawaiannya sesuai dengan peraturan perundang-undangan.

4. Dalam hal atasan langsung sebagaimana dimaksud pada ayat (1) tidak ada, maka pembebasan sementara dari jabatannya dilakukan oleh pejabat yang lebih tinggi.

\section{Pasal 28}

1. Berita acara pemeriksaan sebagaimana dimaksud dalam Pasal 24 ayat (2) harus 
ditandatangani oleh pejabat yang memeriksa dan PNS yang diperiksa.

2. Dalam hal PNS yang diperiksa tidak bersedia menandatangani berita acara pemeriksaan sebagaimana dimaksud pada ayat (1), berita acara pemeriksaan tersebut tetap dijadikan sebagai dasar untuk menjatuhkan hukuman disiplin.

3. PNS yang diperiksa berhak mendapat foto kopi berita acara pemeriksaan sebagaimana dimaksud pada ayat (1).

\section{Pasal 29}

1. Berdasarkan hasil pemeriksaan sebagaimana dimaksud dalam Pasal 24 dan Pasal 25 pejabat yang berwenang menghukum menjatuhkan hukuman disiplin.

2. Dalam keputusan hukuman disiplin sebagaimana dimaksud pada ayat (1) harus disebutkan pelanggaran disiplin yang dilakukan oleh PNS yang bersangkutan.

\section{Pasal 30}

1. PNS yang berdasarkan hasil pemeriksaan ternyata melakukan beberapa pelanggaran disiplin, terhadapnya hanya dapat dijatuhi satu jenis hukuman disiplin yang terberat setelah mempertimbangkan pelanggaran yang dilakukan.

2. PNS yang pernah dijatuhi hukuman disiplin kemudian melakukan pelanggaran disiplin yang sifatnya sama, kepadanya dijatuhi jenis hukuman disiplin yang lebih berat dari hukuman disiplin terakhir yang pernah dijatuhkan.

3. PNS tidak dapat dijatuhi hukuman disiplin dua kali atau lebih untuk satu pelanggaran disiplin.

4. Dalam hal PNS yang dipekerjakan atau diperbantukan di lingkungannya akan dijatuhi hukuman disiplin yang bukan menjadi kewenangannya, Pimpinan instansi atau Kepala Perwakilan mengusulkan penjatuhan hukuman disiplin kepada pejabat pembina kepegawaian instansi induknya disertai berita acara pemeriksaan.

\section{Pasal 31}

1. Setiap penjatuhan hukuman disiplin ditetapkan dengan keputusan pejabat yang berwenang menghukum.

2. Keputusan sebagaimana dimaksud pada ayat (1) disampaikan secara tertutup oleh pejabat yang berwenang menghukum atau pejabat lain yang ditunjuk kepada PNS yang bersangkutan serta tembusannya disampaikan kepada pejabat instansi terkait.

3. Penyampaian keputusan hukuman disiplin sebagaimana dimaksud pada ayat (2) dilakukan paling lambat 14 (empat belas) hari kerja sejak keputusan ditetapkan.

4. Dalam hal PNS yang dijatuhi hukuman disiplin tidak hadir pada saat penyampaian keputusan hukuman disiplin, keputusan dikirim kepada yang bersangkutan.

B. Hambatan-hambatan yang timbul dalam meningkatkan kedisiplinan Pegawai Negeri Sipil pada Kejaksaan Tinggi Kalimantan Timur.

Penerapan peraturan disiplin Pegawai Negeri Sipil berdasarkan Peraturan Pemerintah Nomor 53 Tahun 2010 di lingkungan Kejaksaan Tinggi Kalimantan Timur telah dilakukan upaya penegakan disiplin. Namun masih belum berjalan dengan maksimal karena masih ada pelaku pelanggar disiplin yang mendapatkan hukuman yang tidak sesuai dengan perbuatan yang dilakukannya.

Hambatan-hambatan yang timbul dalam meningkatkan Kedisplinan Pegawai Negeri Sipil pada Kejaksaan Tinggi Kalimantan adalah kurang tegasnya pimpinan dalam memberikan penjatuhan hukuman disiplin terhadap Pegawai yang melakukan pelanggaran disiplin dan kurangnya pehamanan Pegawai dalam memahami Peraturan Pemerintah Nomor 53 Tahun 2010 sehingga banyak pegawai melakukan pelanggaran yang sama contohnya tidak pernah mengikuti apel pagi dan apel sore, dan cukup banyak juga pegawai yang tidak mengikuti senam pagi yang diadakan pada halaman kantor Kejaksaan Tinggi Kalimantan Timur, tetapi tidak dilakukan penjatuhan hukuman disiplin ataupun teguran, sehingga hal ini apabila terus dibiarkan berlanjut maka akan memicu penurunan tingkat kedisiplinan bahkan cenderung menular kepada pegawai yang lain yang sebelumnya rajin. Hal ini dikarenakan tidak adanya perbedaan perlakuan antara pegawai yang rajin dengan yang kurang rajin. Kegiatan apel pagi dan senam pagi merupakan upaya pembinaan disiplin sebagaimana yang telah diatur dalam peraturan Jaksa Agung Republik Indonesia Nomor: PER016/A/J.A/07/2013 tentang urusan dalam dilingkungan Kejaksaan Republik Indonesia 
dalam pasal 15 (lima belas) yang mengatur tentang kegiatan apel pagi hari Senin dan apel sore pada hari Jum'at, sedangkan pasal 128 (seratus dua puluh delapan) yang mengatur tentang kegiatan senam pagi pada hari Jum'at. Penjatuhan hukuman disiplin tingkat ringan berupa teguran lisan kepada kedua 2 (dua) orang pegawai yang tidak menjalankan surat perintah tugas tersebut di nilai belum maksimal kerena belum bisa memberikan efek jera terhadap pelanggar dan pegawai yang lain, tentu saja hal ini akan menghambat pelaksanaan dan penerapan peraturan disiplin itu sendiri.

Dari hasil wawancara dengan KepalaSub. Bagian Kepegawaian Kurangnya pegawai sebagai perangkat pelaksanaan penegakan disiplin yaitu di bidang pengawasan dan kurangnya fasilitas serta sarana dan prasarana dalam pelaksanaan tugas, serta kurangnya sistem pengawasan dalam bekerja maka memungkinkan terjadinya pelanggaran disiplin. Dengan memahami arti pentingnya kedisiplinan Pegawai Negeri Sipil dalam pembangunan, terutama pada lingkungan Kejaksaan, kiranya menjadi kewajiban Pegawai Negeri Sipil dalam melaksanakan kedisiplinan yaitu melaksanakan tugas dan kewajibannya dengan penuh tanggung jawab, dengan demikian kedisiplinan Pegawai Negeri Sipil akan dapat tercapai.

Setiap Pimpinan Kejaksaan Tinggi maupun Kejaksaan Negeri harusnya memberikan sosialisasi terhadap masingmasing pegawai agar masing-masing pegawai mengetahui kewajiban dan larangan yang tercantum dalam Peraturan Pemerintah Nomor 53 Tahun 2010 serta hukuman disiplin bagi masing-masing pegawai agar pegawai mengetahui hukuman disiplin yang diberikan kepada pegawai yang melakukan pelanggaran disiplin. Sehingga setiap pegawai di Kejaksaan Tinggi maupun di Kejaksaan Negeri tidak melakukan Pelanggaran Disiplin. Setiap pimpinan juga harus tegas dalam memberikan hukuman disiplin ditujukan sebagi shock therapy terhadap pegawai yang melakukan pelanggarandan sebagai pelajaran bagi pegawai yang lain untuk tidak melakukan pelanggaran.

Contoh pelanggaran disiplin berat oleh oknum Jaksa atas nama Didik Wahyu Widodo, SH selaku Jaksa Penuntut umum dalam penanganan perkara tindak pidana umum atas nama Terdakwa Rusmin Als Allo Bin daeng Mapile dan kawan-kawan, terlapor tidak melaksanakan tugas dengan baik yaitu pada saat menerima barang bukti berupa 1 (satu) bungkus sabu-sabu berat sekitar 48,51 gram namun disisihkan sebanyak $0,5 \mathrm{gram} / 0,3$ gram netto serbuk dari penyidik yang tidak disegel namun terlapor tidak meminta ahli untuk dilakukan penelitian khusus, selanjutnya terlapor meminjam/ mengambil barang bukti 1 (satu) bungkus sabu-sabu tersebut dari petugas barang bukti dengan alasan untuk siding padahal sebenarnya tidak sesuai dengan jadwal sidang dan terlapor tidak mengembalikan segera setelah keperluan persidangan selesai kepada petugas barang bukti namun menyimpannya sendiri sampai lebih dari 1 (satu) bulan, sehingga menyebabkan barang bukti berupa 1 (satu) bungkus/ paket sabu-sabu tersebut ketika diperlihatkan dalam pemeriksaan di persidangan, dibantah oleh saksi Sugiyanto Bin Beta, Rahmad Bin Abdul Rasyid (saksi penangkap), karena diperkirakan berkurang jumlahnya dan kemasan plastiknya berbeda dengan saat penangkapan dan setelah diuji ulang oleh balai POM samarinda ternyata tidak mengandung metamfetamina. Yang bersangkutan telah melanggar pasal 10 angka 3 dan angka 7 jo pasal 7 ayat (4) huruf c Peraturan Pemerintah Nomor 53 Tahun 2010 tentang disiplin Pegawai Negeri Sipil, dengan dijatuhi hukuman tingkat berat berupa pembebasan dari jabatan fungsional jaksa.

Berdasarkan hasil tes air seni (urine) yang dilakuakan oleh petugas Badan Narkotika Nasional Provinsi Kalimantan Timur terhadap oknum Jaksa Didik Wahyu Widodo, SH didapatkan hasil bahwa yang bersangkutan positif menggunakan sabu-sabu (metamfetamina). Seharusnya Didik Wahyu Widodo, SH dapat dikatagorikan sebagai pemakai dan melanggar Undang-undang Republik Indonesia Nomor 35 tahun 2009 tentang Narkotika, tetapi yang bersangkutan tidak dilakukan hukuman apa-apa selain pembebasan dari jabatan fungsional jaksa. Tentu saja hukuman tersebut tidak membuat yang bersangkutan merasa jera ataupun berubah.

Hal ini bisa dilihat ketika beberapa bulan kemudian setelah penjatuhan hukuman disiplin tersebut, tepatnya pada tanggal 15 September 
2014 yang bersangkutan ditangkap oleh anggota Reserse Narkoba Polresta Samarinda karena yang bersangkutan diduga keras melakukan tindak pidana sebagaimana dimaksud dalam pasal 114 ayat 1 dan pasal 112 ayat 1 UU RI No. 35 Tahun 2009 tentang Narkotika. Sampai sekarang masih dilakukan penahanan oleh pihak penyidik kepolisian. Hal ini tentu sangat mencoreng nama baik institusi kejaksaan, khususnya Kejaksaan Tinggi Kalimantan Timur. Tentu saja dalam kasus ini bidang pengawasan tidak bisa mengawasi Didik Wahyu Widodo, SH secara optimal selama 24 jam karena terbatasnya jumlah personel pada bidang pengawasan, tetapi apabila mengacu pada undang-undang psikotropika yang menjelaskan bahwa apabila ada seseorang menggunakan narkoba yang mengakibatkan ketergantungan terhadap narkoba itu sendiri maka harus dilakukan proses rehabilitasi untuk memulihkan fisik dan mentalnya sebagai pengguna narkoba.

Selain hukuman untuk pembuat, pengedar dan pengguna Narkotika, Pemerintah juga membuat batasan tertentu untuk melakukan rehabilitasi bagi seseorang yang telah menjadi pecandu. Beberapa ketentuan tersebut terdapat dalam Peraturan pemerintah Republik Indonesia Nomor 25 Tahun 2011, tentang Pelaksanaan Wajib Lapor Pecandu Narkotika. Dalam ayat 6 (enam) Peraturan Pemerintah Nomor 25 Tahun 2011 mengatakan Rehabilitasi Medis adalah suatu proses kegiatan pengobatan secara terpadu untuk membebaskan pecandu dari ketergantungan Narkotika, dan dalam ayat 7 (tujuh) Rehabilitasi Sosial adalah suatu proses kegiatan pemulihan secara terpadu, baik fisik, mental maupun sosial, agar mantan Pecandu Narkotika dapat kembali melaksanakan fungsi sosial dalam kehidupan bermasyarakat.

Seandainya pada saat penanganan kasus pertama dari saudara Didik wahyu Widodo, SH yang dijatuhkan hukuman tingkat berat berupa pencopotan dari jabatan fungsional jaksa yang bersangkutan di masukan ke panti rehabilitasi pengguna narkoba karena yang bersangkutan terbukti positif menggunakan narkoba pada saat dilakukan tes urin. Karena telah di nyatakan positif menggunakan narkoba maka harusnya patut di curigai bahwa yang bersangkutan akan ketergantungan terhadap narkoba, maka seharusnya dapat di ambil langkah yang tepat untuk memulihkan fisik dan mental nya agar tidak ketergantungan terhadap narkoba. Apalagi setelah kasus yang di alaminya yang mengakibatkan pencopotan dari jabatan jaksa terhadap yang bersangkutan tentu saja membuat nya frustasi dan bias saja untuk menenangkan pikirannya dia akan menggunakan narkoba lagi. Harusnya pimpinan dan perangkat pelaksana penegakan disiplin dalam hal ini bidang pengawasan harus melakukan pemantauan dan memberikan perhatian khusus, agar setiap perubahan tingkah laku nya bisa di ketahui sehingga bisa di ambil langkah yang tepat dalam penanganannya.

\section{PENUTUP KESIMPULAN DAN SARAN}

Berdasarkan hasil pembahasan mengenai "Pelaksanaan Disiplin Pgawai Negeri Sipil Berdasarka Peraturan Pemerintah Nomor 53 Tahun 2010 Tentang Disiplin Pegawai Negeri Sipil pada Kejaksaan Tinggi Kalimantan Timur" maka dapat disimpulkan bahwa secara umum pelaksanaan kedisiplinan Pegawai Negeri Sipil dilingkungan Kejaksaan Tinggi Kalimantan Timur sudah dilakukan sesuai dengan Peraturan Pemerintah Nomor 53 Tahun 2010. Namun ada beberapa hambatan dalam pelaksanaan secara teknis dilapangan yaitu pada Kejaksaan Tinggi Kalimantan Timur masih kekurangan personel, sehingga beban tugas terlalu banyak sehingga menimbulkan kejenuhan pada personel tersebut, hal ini memungkinkan timbulnya suatu tindakan yang melanggar disiplin Pegawai Negeri sipil. Kurangnya pegawai sebagai perangkat pelaksana penegakan disiplin yaitu di bidang pengawasan di Kejaksan Tinggi dan Kejaksaan Negeri di seluruh wilayah Kalimantan Timur. Karena kurangnya fasilitas serta sarana dan prasarana dalam pelaksanaan tugas, serta kurangnya sistem pengawasan dalam bekerja maka memungkinkan terjadinya pelanggaran disiplin. Dengan memahami arti pentingnya kedisiplinan Pegawai Negeri Sipil dalam pembangunan, terutama pada lingkungan Kejaksaan, kiranya menjadi kewajiban Pegawai Negeri Sipil dalam melaksanakan kedisiplinan yaitu melaksanakan tugas dan kewajibannya dengan penuh tanggung jawab, dengan demikian kedisiplinan Pegawai Negeri 
Sipil akan dapat tercapai. Jika penegakan peraturan disiplin tidak dijalankan dengan baik, maka akan menjadi acuan bagi pegawai yang lain kedepannya dengan dalih membandingkan pelanggaran terdahulu yang tidak diberikan hukuman yang sesuai aturan, tentu saja hal seperti ini akan menghambat pelaksanaan penegakan disiplin pegawai negeri sipil.

Hambatan-hambatan yang timbul dalam meningkatkan disiplin pegawai Kurang tegasnya Sanksi yang diberikan oleh Pejabat yang berwenang. Pejabat yang berwenang harus memberikan sanksi/tindakan secara tegas bilamana seorang Pegawai Negeri Sipil terbukti melakukan pelanggaran disiplin dengan tujuan untuk memberikan efek jera dan shock terapi agar PNS yang lain tidak meniru atau melakukannya.Ancaman yang ditimbulkan apabila penerapan sanksi dalam pelanggaran disiplin PNS tidak dijalankan dengan baik maka akan timbul kecemburuan sosial serta akan dijadikan patokan oleh pegawai yang melanggar peraturan disiplin berikutnya, dengan demikian penerapan sanksi yang tidak sesuai akan menimbulkan menurunnya kepercayaan pegawai terhadap penerapan peraturan disiplin itu sendiri serta memungkinkan meningkatnya pelanggaran terhadap disiplin. Untuk itu hendaknya dalam penerapan sanksi harus sesuai dengan tingkat pelanggaran dan bisa memberikan efek jera terhadap pegawai yang melanggar.

Oleh karenanya penulis memiliki saran yaitu sebaiknya pelaksanaan Peraturan Disiplin Pegawai Negeri Sipil hendaknya dilaksanakan dengan tegas tanpa ada pengecualian, agar peraturan itu sendiri bisa dilaksanakan dengan maksimal. Untuk mendapatkan pencapaian hasil kinerja yang sesuai dengan apa yang diharapkan maka dibutuhkan sumber daya manusia yang berkompetensi di bidang nya serta jumlahnya sesuai dengan beban kerja yang di embannya, jika beban kerja melebihi kemampuan pegawai maka pekerjaan ada yang terbengkalai serta menimbulkan kejenuhan terhadap pegawai sehingga memicu pelanggaran terhadap disiplin. Pembangunan aparatur pemerintahan diarahkan untuk menciptakan aparatur yang lebih efisien, bersih dan berwibawa serta mampu melaksanakan seluruh tugas umum dan pembangunan dengan sebaik-baiknya.
Hendaknya ada sanksi yang tegas terhadap setiap pelanggar disiplin Pegawai Negeri Sipil agar penegakan disiplin bisa berjalan dengan maksimal sehingga bisa menimbulkan rasa jera terhadap pegawai yang melanggar disiplin dan bisa menjadi pedoman atau gamabaran bagi pegawai lain agar tidak melakukan perbuatan yang melanggar disiplin. Untuk melaksanakan peraturan disiplin sesuai dengan peraturan maka sangat dibutuhkan perubahan pola pikir dari masing-masing individu pegawai, agar bisa merubah budaya kerja yang negatif menjadi budaya kerja yang positif.

\section{DAFTAR PUSTAKA}

\section{A. Literatur}

Basrief Arief, Jaksa Sahabat Masyarakat Suatu Harapan, Gaung Persada Press, Jakarta, 2013.

Buchari Alma, Pengantar Bisnis, Alfabeta, Bandung, 2009.

Brantas, Dasar-Dasar Manajemen, Alfabeta, Bandung, 2013.

Brisma Renaldi, Pola Pikir Pegawai Negeri

Sipil, Modul Pendidikan Pelatihan pra Jabatan Gol. II, LAN RI, Jakarta, 2009.

H.M. Agus Santoso, Hukum Moral, dan Keadilan, Sebuah Kajian Filsafat Hukum, Jakarta, 2012.

Idup Suhady, Kepemerintahan yang Baik, Modul Pendidikan dan Pelatihan Pra

Jabatan Gol. II, LAN RI, Jakarta, 2009.

Irham Fahmi, Pelaku Organisasi Teori, Aplikasi, dan Kasus, Alfabeta, Bandung, 2013.

Juniarso Ridwan, dan H.M Achmad Sodik

Sudrajat, Hukum Administrai Negara dan Kebijakan Pelayanan Publik, Nuansa, Bandung, 2010.

Miftah Thoha, Manajemen Kepegawaian Sipil di Indonesia, Jakarta, 2010.

Muhammad Djafar Saidi, Hukum Keuangan Negara, Jakarta, 2010.

Suratman, Philip Dillah, Metode Penelitian Hukum, Alfa Beta, Bandung, 2013.

Soeryono Soekanto, Pengantar Penelitian Hukum, UI Pers, Jakarta, 2010. 
Wilson Bangun, Manajemen Sumber Daya Manusia, Erlangga, Jakarta, 2012.

Wirawan, Evaluasi Kinerja Sumber Daya Manusia, teori, Aplikasi, dan Penelitian,

Salemba Empat, Jakarta, 2009.

\section{B. Daftar Perundang-Undangan}

- Undang-Undang Dasar Tahun 1945 Amandemen.

- Undang-Undang Nomor 5 Tahun 2014, tentang Aparatur Sipil Negara (ASN)

- Undang-Undang Nomor 16 Tahun 2004, tentang Kejaksaan Republik Indonesia

- Undang-Undang No. 43 Tahun 1999, tentang Pokok-Pokok Kepegawaian

- Peraturan Pemerintah No. 46 Tahun 2011, tentang Penilian Prestasi Kerja Pegawai Negeri Sipil.

- Peraturan Pemerintah No. 53 Tahun 2010, tentang Disiplin Pegawai Negeri Sipil.

- Peraturan Pemerintah No. 38 Tahun 2010, tentang Organisasi dan Tata Kerja

Kejaksaan Republik Indonesia.

- Peraturan Pemerintah No. 9 Tahun 2003, tentang Wewenang Pengangkatan,

Pemindahan, Pemberhentian Pegawai Negeri Sipil.

- Peraturan Presiden Republik Indonesia No. 38 Tahun 2010, tentang Organisasi dan Tata Kerja Kejaksaan Republik Indonesia.

- Peraturan Jaksa Agung RI Nomor: Per-016/A/JA/07/2013, Tentang urusan dalam Kejaksaan Republik Indonesia.

- Peraturan Jaksa Agung RI Nomor: PER/009/A/JA/01/2011, tentang Organisasi dan Tata Kerja Kejaksaan Republik Indonesia.

- Peraturan Jaksa Agung RI Nomor : KEPJA/A/JA/12/2000, tentang Ketentuan-

Ketentuan Penyelenggaraan pengawasan Kejaksaan RI JAksa Agung

Republik Indonesia.
- Surat Edaran Kepala Badan Administrasi Kepegawaian Nomor : 23/SE/1980,

Tentang Peraturan Disiplin Pegawai Negeri Sipil.

\section{Media Cetak}

Kaltim Post.

Samarinda Post.

D. Media Internet.

Wirasaputra23.blogspot.com/2013/07 www.kejaksaan.go.id. 